\title{
How group-buying servicescape affect consumers' purchase intention, the regulating effects of price discount and time pressure
}

\author{
Lingying Zhang ${ }^{1}$, Chunling Zhang, ${ }^{1, *}$, Cui Li ${ }^{1}$ and Kang Wang ${ }^{1}$ \\ ${ }^{1}$ College of Management, Shenzhen University, Shenzhen 518060, PR China
}

\begin{abstract}
This paper constructs a conceptual model of how group-buying servicescape affect consumers' purchase intention and discusses the regulating effects of price discount and time pressure. This research uses a survey approach to collect data, as a result, we collected 506 valid questionnaires. The results show that aesthetic appeal, information exchange, interpersonal interaction and perceived security have a positive effect on positive emotion; layout and functionality, information exchange and interpersonal interaction have a positive effect on virtual touch. Positive emotion and virtual touch can promote the consumer's purchase intention, and time pressure and price discount play a regulatory function. The results of this study have an important reference value for group-buying operators to use servicescape to attract and retain consumers.
\end{abstract}

Keywords - group-buying servicescape, virtual touch, positive emotion, group-buying intention.

\section{Introduction}

Group-buying as a new e-commerce model, through the consumer self-group and professional group-buying web site to enhance the bargaining power of customers and businesses. China Group-buying rise later than abroad, group-buying is in the budding period in the year of 2005 and 2006, and enter the stage of vigorous development until in the year 2010. After several years of development, there are many third-party group-buying web site, such as meituan.com, lashou.com, nuomi.com, manzuo.com, 55.com, etc. According to iResearch released data showed that in the first half of 2016, China group-buying market turnover reached 77.01 billion yuan, compared with the same period in 2015 increased by $167.7 \%$. Nevertheless, (Lloyd C Harris \& Goode, 2004) [1] study said that commentator had found that some group-buying e-tailers fail to make profits. Considering the universality of such views, it is perhaps not surprising to find a growing body of research that is identifying and exploring the myriad of factors that may account for the attitudes and behaviors of online shoppers. Therefore, to explore the impact of groupbuying servicescape on consumer's purchase intention, will help operators to create a good shopping environment, so as to attract and retain more consumers.

This research belongs to the literature on aspects of servicescapes. This paper have three objectives. Firstly, to determine whether online group-buying servicescape (physical service environment, social interaction and financial security) has significant relationship with emotional cognition (positive emotion and virtual touch). Secondly, to explore the relationship between emotional cognition (positive emotion and virtual touch) and purchase intention. Thirdly, to study the regulating role of time pressure and price discount on emotional cognition and purchase intention.

\section{Literature review}

\subsection{Group-buying servicescape}

The context of service encounters has been conceptualized a number of scholars using various terms. For example, (Turley \& Milliman, 2000) [2] defined it as marketing environment, (Tai \& C., 2003) [3] defined the online shopping as store environment. The term "servicescape" is created by (Bitner, 1992) [4]. (Lloyd C Harris \& Ezeh, 2008)[5] proposed that the concept of a network servicescape and defined it as all environmental factors in the process of network service delivery (from pre-purchase to post-purchase), which was widely accepted and became a generic term. There are two main aspects of the research on the network servicescape, one aspect is the division of the dimension, another aspect is about the influence on the online behavior of the consumers.

Different people have different perspectives about the division of servicescape. Traditional store servicescape not only includes the physical factors of visualization in the service scenario, but also includes the social factors of interpersonal interaction. (Baker, Grewal, \& Parasuraman, 1994) [6] proposed that traditional store servicescape consists of three factors, including atmosphere factors, design factors and social

Corresponding author: 1715167698@qq.com 
factors. In contrast, (Bitner, 1992) [4] argued that store servicescape is made of ambient conditions, layout and functionality, and signs, symbols, and artifacts. Later scholars adopt this concept in many offline stores study. For example, (Wakefield \& Blodgett, 2013) [7] apply this concept into their study about the servicescape of leisure service settings. However, the advent of Internet and information technology, making a lot of scholars begin to study online network servicescape. (Eroglu, Machleit, \& Davis, 2003) [8] divided the online store atmospherics into high-mission-related factors and lowmission-related factors based on media richness theory. (Kim, Kim, \& Kandampully, 2009) [9] divided the online store servicescape into six dimensions: convenience, customization, informality, interaction, the appearance of the site and the value of entertainment. (Lloyd C. Harris \& Ezeh, 2008) [5] argued that the online servicescape should be consist of three dimensions, including aesthetic appeal, functional layout and financial security.

There are two paths to the study of the influence of online servicescape on consumer behavior. One path is based on S-O-R. It is believed that emotional reaction is the intermediary of online servicescape and consumer reaction. With the deepening of research, many scholars realize that the relationship between emotional stimuli and consumer behavior is explained partly. Therefore, some scholars introduce customer cognition as another rese arch path. (Kim et al., 2009) [9] proved that the online servicescape positively affects customer perceived service quality and satisfaction, which leads to customer buying behavior.

\subsection{Group-buying interaction}

Online group-buying is a novel business model. Based on the number of units a group buys, consumers have a motivation to regroup for unit price reduction. With the purchasing amount increases, consumers will receive lower product prices. (Matsuo, 2009)'s [10] research showed that group-buying enables consumers to gain volume discounts and discounted group prices when consumers aggregate the requested group size. At present, there are many third-party group-buying web site, such as meituan.com, lashou.com, nuomi.com, manzuo.com, 55.com, etc. It can be seen, the trend of group-buying socialization has been strengthened, the consumer interaction in group-buying has become an inevitable trend, but the existing group-buying literature less concerned about the interaction between users.

(Florenthal \& Shoham, 2010) [11] defined groupbuying interaction as the degree to which one or more individuals respond to the behavior of a particular information provider. (Bonfield, 1974) [12] pointed that the members of group-buying often share the purchase experience. (Shan, Luo, \& Zhang, 2013) [13] put forward that the interaction between customers is divided into two types: information exchange and social interaction, the purpose of information exchange is to obtain certain information to solve the problem, social interaction is in order to obtain emotional satisfaction through chatting on the Internet.

\subsection{Virtual touch}

In recent years, sensory research on the field of consumers has begun to receive attention in the world, especially tactile research is on the rise. (Peck, Barger, \& Webb, 2013)[14] thought that tactile is a direct experience of the consumer on the goods. (Reb \& Connolly, 2007)'s [15] research showed that the touch can narrow the emotional distance between the two sides and thus affect the consumer's attitude to the goods and purchase behavior. (Grohmann, Spangenberg, \& Sprott, 2007)[16] argued that the tactile elements of a commodity can inspire consumers' favor sense and emotional involvement to change buying decisions. (Citrin, Jr, Spangenberg, \& Clark, 2003) [17] proposed that a shortcoming of Internet-based retailing efforts is consumers' inability to touch products during their purchase decision-making processes, the results show that women have a higher need for tactile input compared to men in making product evaluations. The Internet and the World Wide Web (WWW) are predicted to become the center of the commercial universe. Customers can touch the product in offline stores, but if they cannot touch the product when making purchase online. (Peck \& Childers, 2003)[18] found that product's intrinsic cues such as tactility, color or smell (cues which, if changed would produce a resultant change in the physical product itself) are more important in a product's perceived quality than its extrinsic cues.

There are many literatures on tactile at present, but there is relatively little literature on virtual touch. Through the integration of a small number of foreign literature, we can clear the formation of virtual tactile mechanism. Because of the interactive function of human organs, enabling the customers produce a tactile experience through the sense of visual and auditory, and creating a telepresence from the overall scene, thus evoking the historical tactile memory, and thus produce tactile perception through the association.

\section{A conceptual model}

\subsection{The relationship between group-buying servicescape and positive emotions}

According to the literature review, the group-buying servicescape can be divided into physical dimension, social dimension and financial security. (Lloyd C. Harris \& Goode, 2004) [1] divided the physical dimension into aesthetic appeal and layout and functionality based on the characteristics of group-buying online. Aesthetic appeal refers to the atmosphere of the attractiveness of the group-buying web site, layout and functionality refers to the organization of the web site, organization, layout and adaptability. Social interaction is divided into information exchange and interpersonal interaction.

Many scholars have confirmed that the online shopping physical environment has an impact on 
consumer sentiment. In terms of aesthetic appeal, (Kawaf \& Tagg, 2012)'s [19] research showed that the text, picture, and music atmosphere in the online shopping environment can significantly affect the consumer's emotion. (Wang, Minor, \& Wei, 2011)[20] suggested that site with a rich media tools, can make the store a better atmosphere, which leading to customer pleasure mood. (Shobeiri, Laroche, \& Mazaheri, 2013)'s [21] study found that the aesthetic factors in the online shopping environment help consumers to immerse them and promote the purchase. In terms of layout and functionality, (Lloyd C. Harris \& Ezeh, 2008)[5] study showed that if shopping sites can be customized, and allow customers to personalize their settings, the customer's satisfaction will increase significantly.

(Rose, Clark, Samouel, \& Hair, 2012)'s [22] study confirmed that the usefulness and customization of the online stores positively affects the customer's pleasure. When consumers browse the group-buying site, physical elements can attract the user's eye and stimulate the user to produce a happy mood. Therefore, the hypothesis 1a, $1 \mathrm{~b}$ is proposed.

H1a: Aesthetic appeal is a positive impact on the group-buying consumer's positive emotions.

H1b: Layout and functionality is a positive impact on the group-buying consumer's positive emotions.

Social media allows consumers who coming from different space to gather together on the Internet, the consumers can communicate with each other. So, some scholars began to focus on the impact of interaction on consumer emotional response. (Lin \& Liang, 2015)[23] believed that the information conveyed by consumer interaction contains some useful clues that give the audience a pleasant feeling. (Fiore \& Jin, 2003)[24] proposed that online interactivity position perceived interactivity as a central driver of consumers' interpretations and behavior. Group-buying users in the virtual community, QQ group and WeChat and other social media interaction group, not only exchange product-related information, but also free communicate personal experience and emotions. So we propose the hypothesis $2 \mathrm{a}, 2 \mathrm{~b}$.

$\mathrm{H} 2 \mathrm{a}$ : Information exchange is a positive impact on the group-buying consumer's positive emotions.

$\mathrm{H} 2 \mathrm{~b}$ : Interpersonal interaction is a positive impact on the group-buying consumer's positive emotions

Online financial security refers to the extent to which consumers perceive the payment processes and general policies of a web site as secure or safe. (Fusaro, Charron, \& Theoret, 2003)[25] thought that perceived security is a crucial aspect of online group-buying servicescape. (Szymanski \& Hise, 2000)'s [26] study showed that perceived safety has a significant impact on customer satisfaction. Safe payment environment can promote the positive emotions of consumers. Therefore:

H3: Perceived security is a positive impact on the group-buying consumer's positive emotions.

\subsection{The relationship between group-buying servicescape and the virtual touch}

With the development of virtual reality technology, the sensory experience of online shopping began to receive attention. (Li, Daugherty, \& Biocca, 2003)[27] proposed that virtual experience is a psychological state which consumers interacts with the commodity in the virtual environment. (Marzocchi, Pizzi, \& Scarpi, 2016)'s [28] study showed that the realization of consumer virtual experience is affected by objective factors, sensory factors, perceptual factors, stimulating response factors, cognitive and affective factors, encounter factors. Commodity quality, price and other marketing factors play a role through the consumer's sensory process. (Mccabe \& Nowlis, 2003)'s [29] research showed that media tools that provide a wealth of product information can effectively compensate for the disadvantages that the goods cannot be touched when shopping online. Therefore, the development of technology allows the group-buying operators to display the product vividly and create a harmonious and comfortable atmosphere of online shopping, which making consumers feel like in the store. Accordingly the hypothesis $4 \mathrm{a}, 4 \mathrm{~b}$ are putted forward.

H4a: Aesthetic appeal is a positive impact on the group-buying consumer's virtual touch.

H4b: Layout and functionality is a positive impact on the group-buying consumer's virtual touch.

Although the development of virtual reality technology can make up for the lack of consumer online shopping sensory experience, but the display of goods and the layout of the site are from the online stores. For consumers, the product information obtained from other customers is more objective and real. Therefore, many consumers may choose to communicate with other consumers online to understand the product. (Skadberg \& Kimmel, 2004)'s [30] study found that the higher the level of interaction, the higher the virtual experience of the consumer. (Zhao, Cai, Shan, University, \& University, 2014)'s [31] study indicate that network marketing tools such as communities, real-time chat, etc., contribute to the generation of high-quality online interactions that inspire the consumer's touch experience. The interaction between consumers can enable consumers to get more information about product and create a good social atmosphere, so that consumers have a sense of presence. So we propose the hypothesis $5 \mathrm{a}, 5 \mathrm{~b}$.

H5a: Information exchange is a positive impact on the group-buying consumer's virtual touch.

$\mathrm{H} 5 \mathrm{~b}$ : Interpersonal interaction is a positive impact on the group-buying consumer's virtual touch.

\subsection{The relationship between emotional cognition and group-buying intention}

The relationship between positive emotions and purchase intention has been proved by many scholars. (Rose et al., 2012)[22] analyzed that how price perception and service awareness awake consumer positive emotions and then affect the final shopping process. But there is relatively little research on the relationship between virtual tactile and purchase intention, (Peck \& Johnson, 2011)'s [32] research showed that touch cannot make 
consumers get enough product information, but can change the consumer's attitude about product and enhance the purchase intention through the sensory experience. (Zhao et al., 2014)'s [31] empirical study showed that online commodity display and online interaction can directly and indirectly affect the consumer impulse to buy, virtual touch plays an indirect role in the incomplete intermediary variables. On the online purchase scenario, although the biggest problem facing consumers is difficult to touch the product, many consumers can not touch the product to give up the final purchase. The maturity of virtual technology can make up for this shortcoming. Visual experience and online interaction can trigger a tactile experience, and consumers get a virtual touch. So this paper think that the virtual touch can affect the purchase intention as the same as the real touch.

H6a: Positive emotions have a positive impact on consumer's group-buying intention

H6b: Virtual touch has a positive impact on consumer's group-buying intention.

\subsection{The regulating role of time pressure and price discount}

(Bonfield, 1974)[12] argued that time pressure refers to the pressure response that consumers are caused by completing shopping decisions within a limited time. In the e-commerce platform, promotional methods of limited time are widely used, namely, with the passage of time and the closing date of the approaching, consumers perceive the lack of time to produce emotional reactions. Although time is an important factor in the decision-making of consumers to buy, less scholars pay attention to the role of time pressure. (Dhar \& Nowlis, 1999)'s [33] study show that when time pressure is large, consumers are more likely to reduce their risk expectations and impulse consumption. (Sepp, 2014)'s [34] research show that time pressure in the situation of group-buying has a positive impact on attitude and purchase intension, in the case of large time pressure, the effect of attitude on purchasing intention is stronger than less time pressure. Limited time purchase is the difference between group-buying and ordinary online shopping, the customers is affected by groupbuying activities and group-buying atmosphere and more inclined to transfer the positive perception into the purchase intention. So we propose the hypothesis $7 \mathrm{a}, 7 \mathrm{~b}$.

H7a: Time pressure have a regulatory role between positive emotions and group-buying intention.

$\mathrm{H} 7 \mathrm{~b}$ : Time pressure have a regulatory role between virtual touch and group-buying intention.

Price is one of the most likely to stimulate consumer desire to purchase, different from ordinary online shopping, the characteristics of group-buying are gathering a certain number of customers to get a low prices. (Rudolph, Bauer, \& Steiner, 2010)'s [35] research shows that the discount rate of advertising will strengthen the impact of consumer's perception on the purchase intention.
(Moon \& Lee, 2013)[36] pointed out that the price discount can adjust the impact of user perception on the purchase decision, the higher the price discount, the higher the customer's perceived value, and then stimulating the purchase behavior of customer. To sum up, in the situation of group-buying, when the consumer has a positive perception of the environment created by online stores, price discounts will stimulate consumers to grasp the chance to buy.

H8a: Price discount has a regulatory role between positive emotions and group-buying intention.

$\mathrm{H} 8 \mathrm{~b}$ : Price discount has a regulatory role between virtual touch and group-buying intention.

The conceptual model of this paper is showed in Figure1.

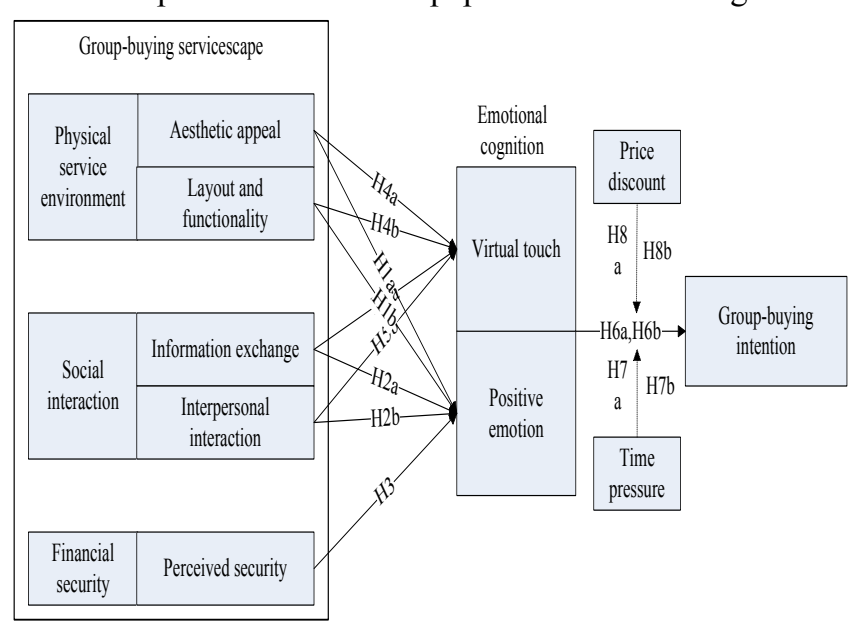

Fig. 1. The conceptual model.

\section{Methodology}

\subsection{Data Collection}

This paper used the form of a questionnaire to verify the hypothesis. We designed an online questionnaire, which is used to collect data. We created a questionnaire link and share it with people through WeChat, e-mail and QQ etc. As a result, we collected 506 valid questionnaires. In terms of gender, there are 271 females and 235 males; in terms of age, in the 15-20 years old accounted for 5.73 percent, in the 21-25 years old accounted for 29.45 percent, in the 26-30 years old accounted for 21.74 percent, in the 31-35 years old accounted for 39.13 percent, more than 35 years old accounted for 3.95 percent; in terms of education, bachelor degree had 318 people, master's degree had 35 people.

\subsection{Measures}

The measurement items in this paper were from previous studies. The items of online survey in this research used 1-5 Likert scales, on which 1-point indicated "strongly disagree" and 5-point "strongly agree". In this paper, we use the first letter of each word in variables plus the number to represent the indicators. The indicator of aesthetic appeal was described as AA1, AA2 and AA3. The same way to define layout and functionality (LF), information exchange (IE), interpersonal interaction (II), 
perceived security (PS), positive emotion (PE), virtual touch (VT), group-buying intention (GI), price discount $(\mathrm{PD})$, price discount $(\mathrm{PD})$.

Table 1. The result of principal component analysis.

\begin{tabular}{|c|c|c|c|c|c|c|c|c|c|c|}
\hline & \multicolumn{10}{|c|}{ Components } \\
\hline & 1 & 2 & 3 & 4 & 5 & 6 & 7 & 8 & 9 & 10 \\
\hline AP1 & .641 & .105 & .236 & .108 & .205 & -.002 & .163 & -.091 & -.131 & -.010 \\
\hline 2 & 37 & 187 & .349 & 284 & .025 & .021 & .125 & .006 & -.014 & .039 \\
\hline P3 & 18 & 313 & 268 & .014 & .096 & -.136 & -.029 & .086 & .072 & .043 \\
\hline AP4 & 09 & .290 & .345 & .243 & -.131 & .010 & .010 & .007 & .007 & .064 \\
\hline LF1 & .477 & .310 & .168 & .564 & -.022 & -.015 & .153 & .037 & .052 & -.201 \\
\hline LF2 & 399 & .315 & 376 & 34 & 212 & .171 & .306 & .088 & .060 & -.07 \\
\hline 93 & 86 & 283 & 02 & 30 & 132 & 128 & -.086 & .128 & .087 & -.05 \\
\hline LF4 & .414 & 279 & .404 & .675 & -.090 & .045 & .279 & -.006 & -.044 & .045 \\
\hline LF5 & .354 & 279 & 237 & 571 & .138 & .051 & -.018 & .195 & .105 & -.04 \\
\hline F6 & 43 & 399 & 79 & 94 & 202 & -.063 & .209 & .073 & 143 & .1 \\
\hline LF7 & .577 & .263 & .252 & .547 & .045 & .110 & .019 & -.015 & .017 & -.092 \\
\hline IE1 & .243 & .393 & .657 & .028 & .120 & .027 & .081 & .179 & .173 & -.072 \\
\hline IE2 & 13 & .307 & 46 & .053 & .017 & 001 & .163 & .030 & .017 & .12 \\
\hline IE3 & .186 & .316 & .518 & .143 & -.135 & -.031 & .096 & .082 & .046 & -.02 \\
\hline IE4 & .334 & .359 & .676 & .163 & .037 & -.024 & -.079 & -.024 & .002 & -.06 \\
\hline II1 & .200 & 0.35 & .385 & .479 & .086 & -.076 & .183 & -.001 & .634 & .017 \\
\hline II2 & .387 & .084 & .218 & .445 & .145 & $\mid$ & -.017 & .052 & .578 & .00 \\
\hline II3 & .334 & .025 & .416 & .465 & .007 & -.051 & .094 & .020 & .628 & -.014 \\
\hline II4 & .209 & .032 & .265 & .365 & .085 & -.019 & .073 & .036 & .682 & -.14 \\
\hline PS1 & .042 & .054 & .012 & .003 & .052 & .954 & -.042 & .443 & .454 & .055 \\
\hline PS2 & -.062 & -.029 & .017 & .036 & .103 & .838 & -.097 & -.002 & -.024 & .02 \\
\hline PS3 & -.014 & .018 & 4 & 92 & 15 & .637 & 94 & .043 & .054 & .90 \\
\hline PS4 & .023 & -.019 & .033 & .037 & .079 & .907 & -.034 & -.027 & -.023 & .055 \\
\hline PS5 & .067 & -.007 & .077 & .075 & .449 & .679 & .096 & .044 & .068 & -.116 \\
\hline PE1 & .472 & .028 & .410 & -.014 & .000 & -.048 & -.058 & \begin{tabular}{|l|l}
.588 \\
\end{tabular} & -.017 & .06 \\
\hline E2 & 38 & .093 & 59 & .058 & -.027 & .074 & .030 & .609 & .056 & -.00 \\
\hline PE3 & .420 & .101 & .349 & -.020 & .027 & -.062 & .036 & .623 & .038 & .047 \\
\hline PE4 & 148 & -.063 & .233 & .188 & -.034 & -.009 & -.165 & .729 & -.012 & .179 \\
\hline PE5 & .316 & .085 & .290 & -.090 & .560 & .160 & .003 & .068 & .063 & -.105 \\
\hline VT1 & .295 & -.218 & .254 & -.039 & .607 & -.103 & -.007 & -.099 & -.072 & .007 \\
\hline VT2 & .127 & .195 & .407 & -.085 & .569 & .097 & .133 & -.076 & -.087 & -.00 \\
\hline GI1 & .347 & .675 & .081 & .034 & -..077 & .247 & .054 & .086 & .047 & -.041 \\
\hline GI2 & .274 & .814 & .368 & .042 & -.127 & .096 & -.087 & .121 & .121 & .072 \\
\hline GI3 & .395 & 58 & .057 & .022 & -.097 & .017 & .064 & .038 & .066 &.- \\
\hline TP1 & 195 & .249 & .694 & .025 & .172 & -.012 & -.094 & -.019 & -.014 & .015 \\
\hline TP2 & .324 & .331 & .531 & -.124 & .169 & .029 & .088 & .055 & -.019 & -.045 \\
\hline TP3 & .194 & .251 & .670 & -.002 & .128 & .063 & -.035 & -.083 & -.091 & -.0 \\
\hline PD1 & -.009 & .451 & .282 & .120 & -.102 & .075 & .025 & .084 & -.091 & .526 \\
\hline PD2 & .083 & .442 & .316 & -.029 & .219 & .040 & $\mid-.069$ & .064 & .060 & .617 \\
\hline PD3 & 067 & .242 & .392 & -.081 & -.206 & .173 & -.096 & .025 & .035 & .510 \\
\hline PD4 & .069 & .322 & .237 & .157 & .309 & -.16 & -.036 & .054 & .037 & .529 \\
\hline
\end{tabular}

\section{Data analysis}

\subsection{Reliability and validity analysis}

Reliability analysis is an effective method to analyze whether the comprehensive evaluation system has a certain stability and reliability, mainly test the stability and consistency of measurement results and measurement tools. This paper used SPSS22.0 software and the widely used Cronbach's alpha to analyze the reliability. The result is showed in Table 2, from Table 2, we can see that the Cronbach's alpha coefficient is all great than 0.70 which indicates that the sample is quite good and commonly acceptable level for explanatory research. Table 1 shows that all the indicators have a high load (all above 0.5) on the respective factors and low on other factors, indicating that the scale has a good structural validity.

Table 2. Analysis of scale reliability.

\begin{tabular}{|c|c|}
\hline Factors & Cronbach's Alpha \\
\hline AA & 0.751 \\
\hline LF & 0.830 \\
\hline IE & 0.751 \\
\hline II & 0.735 \\
\hline PS & 0.800 \\
\hline PE & 0.780 \\
\hline VT & 0.749 \\
\hline GI & 0.751 \\
\hline TP & 0.721 \\
\hline PD & 0.747 \\
\hline
\end{tabular}

\subsection{Regression analysis}

According to the conceptual model and research hypothesis, we need multiple regression analysis of three sets of variables. Three sets of variables are groupbuying servicescase and emotional cognition, emotional cognition and group-buying intention and the regulating role of time pressure and price discount.

\subsubsection{Group-buying servicescase and emotional cognition}

This paper use spss22.0 software to stepwise regression, the result of regression analysis of the group-buying servicescape and emotional cognitive is shown in Table 3 and Table 4.

In all dimensions of group-buying, the results of regression analysis show that the positive effect of aesthetic appeal, information exchange, interpersonal interaction, perceived security on positive emotion is supported, but layout and functionality failed to enter the positive emotion of this model, so its positive role is not 
supported. The positive effect of layout and functionality, information exchange and interpersonal interaction on virtual touch get support, however, aesthetic appeal did not enter the virtual touch of the model, so their positive role is not supported.

Table 3. The results of regression analysis of group-buying servicescape and positive emotion.

\begin{tabular}{|c|c|c|c|c|c|}
\hline $\begin{array}{c}\text { Independent } \\
\text { Variables }\end{array}$ & $\begin{array}{c}\text { Normalization } \\
\text { coefficient }\end{array}$ & $\begin{array}{c}\text { T } \\
\text { Value }\end{array}$ & $\begin{array}{c}\text { Signifi- } \\
\text { cance } \\
\text { level }\end{array}$ & VIF & $\begin{array}{c}\text { D.W } \\
\text { Value }\end{array}$ \\
\cline { 1 - 4 } AA & 0.398 & 5.758 & 0.000 & \multirow{2}{*}{1.048} & \multirow{2}{*}{1.803} \\
\cline { 1 - 4 } IE & 0.311 & 4.646 & 0.000 & & \\
\cline { 1 - 4 } II & 0.283 & 3.603 & 0.001 & & \\
\hline PS & 0.374 & 5.036 & 0.000 & & \\
\hline
\end{tabular}

Table 4. The results of regression analysis of group-buying servicescape and virtual touch.

\begin{tabular}{|c|c|c|c|c|c|}
\hline $\begin{array}{c}\text { Independent } \\
\text { Variables }\end{array}$ & $\begin{array}{c}\text { Normalization } \\
\text { coefficient }\end{array}$ & $\begin{array}{c}\text { T } \\
\text { Value }\end{array}$ & $\begin{array}{c}\text { Signifi- } \\
\text { cance } \\
\text { level }\end{array}$ & VIF & $\begin{array}{c}\text { D.W } \\
\text { Value }\end{array}$ \\
\cline { 1 - 4 } LF & 0.119 & 1.988 & 0.000 & \multirow{2}{*}{1.003} & \multirow{2}{*}{1.766} \\
\hline IE & 0.291 & 4.879 & 0.000 & & \\
\hline II & 0.408 & 6.793 & 0.004 & & \\
\hline
\end{tabular}

\subsubsection{Emotional cognition and group-buying}

The results of regression analysis of emotional recognition and group-buying intention is shown in Table 5. The regression analysis results show that the two factors of the emotional cognition are entered into the model, and the positive effects of positive emotion and virtual touch on the group-buying intention are supported.

Table 5. The results of regression analysis of emotional recognition and group-buying intention.

\begin{tabular}{|c|c|c|c|c|c|}
\hline $\begin{array}{c}\text { Independent } \\
\text { Variables }\end{array}$ & $\begin{array}{c}\text { Normalization } \\
\text { coefficient }\end{array}$ & $\begin{array}{c}\text { T } \\
\text { Value }\end{array}$ & $\begin{array}{c}\text { Signifi- } \\
\text { cance } \\
\text { level }\end{array}$ & VIF & $\begin{array}{c}\text { D.W } \\
\text { Value }\end{array}$ \\
\hline PE & 0.710 & 7.065 & 0.000 & \multirow{2}{*}{1.341} & \multirow{2}{*}{2.097} \\
\hline VT & 0.673 & 2.758 & 0.006 & \\
\hline
\end{tabular}

\subsubsection{The regulatory effect of time pressure and price discount}

The effect of time pressure and price discount on positive emotion and group-buying intention. In this paper, the positive emotion, time pressure, price discount, the product of positive emotion multiply time pressure and positive emotion multiply price discount are taken as independent variable; group-buying intention is taken as dependent variable. Multi-layer regression analysis is the main method to analyze the regulatory effects of time pressure and price discount. The results are shown in Table 6.

According to the regression analysis results in Table 6 , it was found that the negative correlation coefficient $\mathrm{R}^{2}$ was strongly changed $(0.018)$ after the time pressure was added, and its significance was 0.001 , which was significant at the $<0.05$ level, indicating that the time pressure was positively correlated with the positive emotion and group-buying intention. In model 3, the negative correlation coefficient of the model was changed (0.011) after adding the price discount factor, and it was also significant at the $<0.05$ level, indicating that the price discount had effect on the positive emotion and the group-buying intention.

Table 6. Time pressure and price discount on positive emotions and group-buying intention regression model coefficient.

\begin{tabular}{|c|c|c|c|c|}
\hline \multirow{2}{*}{ Model } & \multicolumn{4}{|c|}{ Model Summary $^{\mathbf{d}}$} \\
\cline { 2 - 5 } & $\boldsymbol{R}$ & $\boldsymbol{R}^{\mathbf{2}}$ & $\boldsymbol{\Delta R}^{\mathbf{2}}$ & Sig. $\boldsymbol{F}$ \\
\hline 1 & $0.751^{\mathrm{a}}$ & 0.564 & 0.564 & 0.000 \\
\hline 2 & $0.763^{\mathrm{b}}$ & 0.582 & 0.018 & 0.001 \\
\hline 3 & $0.770^{\mathrm{c}}$ & 0.593 & 0.011 & 0.000 \\
\hline
\end{tabular}

Note: a predictor variables are (constant), time pressure, positive emotion, price discount; $\mathrm{b}$ predictor variables are (constant), time pressure, positive emotion, price discount, the product of positive emotion multiply time pressure; c predictor variables are (constant), time pressure, positive emotion, price discount, the product of positive emotion multiply time pressure and positive emotion multiple price discount; $d$ as group-buying intention presents dependent variable.

The effect of time pressure and price discount on virtual touch and group-buying intention. In this paper, virtual touch, time pressure, price discount, the product of virtual touch multiply time pressure and virtual tactile multiply price discount are used as independent variable, group-buying intention is taken as dependent variable. Multi-layer regression analysis is the main method to analyze the regulatory effects of time pressure and price discount. The results are shown in Table 7.

Table 7. Time pressure and price discount on the virtual touch and group-buying intention of the regression model coefficient.

\begin{tabular}{|c|c|c|c|c|}
\hline \multirow{2}{*}{ Model } & \multicolumn{4}{|c|}{ Model Summary $^{\mathrm{d}}$} \\
\cline { 2 - 5 } & $\boldsymbol{R}$ & $\boldsymbol{R}^{\mathbf{2}}$ & $\boldsymbol{\Delta R}^{2}$ & Sig. $\boldsymbol{F}$ \\
\hline 1 & $0.715^{\mathrm{a}}$ & 0.511 & 0.511 & 0.000 \\
\hline 2 & $0.723^{\mathrm{b}}$ & 0.523 & 0.012 & 0.000 \\
\hline 3 & $0.730^{\mathrm{c}}$ & 0.533 & 0.010 & 0.004 \\
\hline
\end{tabular}

Note: a predictor variables are (constant), time pressure, virtual touch, price discount; b predictor variables are (constant), time pressure, virtual touch, price discount, the product of virtual touch multiply time pressure; c predictor variables are (constant), time pressure, virtual touch, price discount, the product of virtual touch multiply time pressure and virtual touch multiple price discount; $d$ as group-buying intention presents dependent variable.

According to the regression analysis results in Table 7 , it was found that the negative correlation coefficient of the model was changed (0.012) after adding the time pressure factor, and its significance was 0.000 , which was significant at the $<0.05$ level, indicating that the time pressure has regulatory effect on the virtual touch and group-buying intention. In model 3, after adding the price discount element, the model negative correlation coefficient $\mathrm{R}^{2}$ is changed (0.010), and significant at the $<0.05$ level, indicating that the price discount on the virtual touch and group-buying intention to have a regulatory role.

\section{Discussion and conclusion}

This paper used empirical research methods to explore the impact of group-buying servicescape on consumer purchasing intention. Most of the assumptions have been proved to be true, only $\mathrm{H} 1 \mathrm{~b}$ and H4a are not supported. 
The research indicates that aesthetic appeal, information exchange, interpersonal interaction and perceived security have a positive effect on positive emotion; layout and functionality, information exchange and interpersonal interaction have a positive effect on virtual touch. Positive emotion and virtual touch can promote the consumer's purchase intention, and time pressure and price discount play a regulatory function. The results of this study have an important reference value for groupbuying operators to use servicescape to attract and retain consumers.

H1a is supported, this means that pictures, colors, text, sound and video display is conducive to mobilize the consumer's emotions. Unexpectedly, $\mathrm{H} 1 \mathrm{~b}$ are not supported, the layout and functionality does not affect the positive emotions, the reason may be that consumers are more concerned about the product itself, customization of online group-buying may is a waste of time. $\mathrm{H} 2 \mathrm{a}$ and $\mathrm{H} 2 \mathrm{~b}$ are supported, the result shows that the social interaction are related to the consumer's emotions. By obtaining real and objective information to enable consumers to get a good mood. And the exchanges of value of life and daily of life also can help they get a good mood. H3 is also supported, a safe environment of group-buying web site will make consumers have a good mood. $\mathrm{H} 4 \mathrm{~b}$ is supported, but $\mathrm{H} 4 \mathrm{a}$ is not supported, the one reason may be that consumers are more concerned about the inherent nature of the product and not concerned about the aesthetic elements of the site, or the other reason may be that consumers bought this product before, they already know the quality of the product, now they want to buy this product again, only the price can cause their attention. H5a and $\mathrm{H} 5 \mathrm{~b}$ are supported, that proves that in the servicescape of group-buying, when the content of the consumer discussion is about the purchase of products, the description of others can objectively realistic display of the actual situation of the product, which contains the product touch thread than the business description easier to let consumers feel the product real existence. H6a and $\mathrm{H} 6 \mathrm{~b}$ are supported, the result shows that in the eservicescape of group-buying, positive emotions and virtual tactile perception can promote the willingness of consumer's group-buying. On the one side, there exists a positive impact on the purchase intention when they are in a good mood. On the other side, one of the important factors of many consumers give up online group-buying is cannot touch the product, and physical dimensions and social dimensions produced by the visual display as a compensation mechanism can make consumers have a virtual touch feel, thereby enhancing the consumer's desire to buy. $\mathrm{H} 7 \mathrm{a}$ and $\mathrm{H} 7 \mathrm{~b}$ are supported, this indicates that group-buying limited time make the consumer have no sufficient time to fully search for information, but in the state of positive emotions and perceived touch experience, the pressure from time led to consumers to make a decision to grasp promotions in time. H8a and $\mathrm{H} 8 \mathrm{~b}$ are supported, indicating that the price discount play a regulatory role in the emotional cognition and group-buying.

At last, we provide some advice to the operators of online group-buying. Firstly, as the development of virtual reality technology, operators can use more advanced technical to display products, and enhance the display effect of products, such as to take 3D display, set the virtual dressing room and real models. Secondly, China's current group-buying web sites are mostly belong to third-party web site which lacking of consumer interaction platform, according to the results of this study, operators can set up a special information exchange platform on the page of group-buying products, then consumers can communicate with other people about the product. At the same time, operators set up a dedicated emotional exchange section on the website, for consumers to engage in social communication to enhance their sense of belonging. Thirdly, due to time pressure and price discount has a significant regulatory role, operators can continue to retain the practice and further strengthen it. For example, setting the countdown time on the buy page. Timekeeping and supplemented by the practice of ticking voice, making customers feel the passage of time through visual and auditory, which can make consumers are more concerned about the factor of time.

\section{Acknowledgments}

This work is partially supported by National Natural Science Foundation of China under Grant No. 71572115; Major Program of Social Science Foundation of Guangdong under Grant No. 2016WZDXM005; National Science Foundation of SZU under Grant No. 836.

\section{References}

1. L. C. Harris and M. M. H. Goode, "The four levels of loyalty and the pivotal role of trust: a study of online service dynamics," Journal of Retailing, vol. 80, pp. 139-158, 2004.

2. L. W. Turley and R. E. Milliman, "Atmospheric Effects on Shopping Experimental Evidence," 2000.

3. A. R. Tai and S. T. C., "Store Environment and Shopping Behavior," Journal of International Consumer Marketing, vol. 15, pp. 71-99, 2003.

4. M. J. Bitner, "Servicescapes: The impact of physical surroundings on customers and employees," Journal of Marketing, vol. 56, pp. 57-71, 1992.

5. L. C. Harris and C. Ezeh, "Servicescape and loyalty intentions: an empirical investigation," European Journal of Marketing, vol. 42, pp. 390-422, 2008.

6. J. Baker, D. Grewal, and A. Parasuraman, "The influence of store environment on quality inferences and store image," Journal of the Academy of Marketing Science, vol. 22, pp. 328-339, 1994.

7. K. L. Wakefield and J. G. Blodgett, "The effect of the servicescape on customers' behavioral intentions in leisure service settings," Journal of Services Marketing, vol. 10, pp. 45-61, 2013.

8. S. A. Eroglu, K. A. Machleit, and L. M. Davis, "Empirical testing of a model of online store 
atmospherics and shopper responses," Psychology \& Marketing, vol. 20, pp. 139-150, 2003.

9. J. H. Kim, M. Kim, and J. Kandampully, "Buying environment characteristics in the context of e service," in Meetings on Acoustics 1 Meeting Acoustical Society of America, 2009, pp. 2155-2167.

10. T. Matsuo, "A REASSURING MECHANISM DESIGN FOR TRADERS IN ELECTRONIC GROUP BUYING," vol. 23, pp. 1-15, 2009.

11. B. Florenthal and A. Shoham, "Four - mode channel interactivity concept and channel preferences," Journal of Services Marketing, vol. 24, pp. 29-41, 2010.

12. E. H. Bonfield, "Attitude, Social Influence, Personal Norm, and Intention Interactions as Related to Brand Purchase Behavior," Journal of Marketing Research, vol. 11, pp. 379-389, 1974.

13. M. Y. Shan, Y. H. Luo, and R. L. Zhang, An Analysis and Empirical Study of the Impact of Customer Relationship Quality on Repurchase Intention in Online Shopping Context: Springer Berlin Heidelberg, 2013.

14. J. Peck, V. A. Barger, and A. Webb, "In search of a surrogate for touch: The effect of haptic imagery on perceived ownership," Journal of Consumer Psychology, vol. 23, pp. 189-196, 2013.

15. J. Reb and T. Connolly, "Possession, feelings of ownership and the endowment effect," Judgment \& Decision Making, vol. 2, pp. 107-114, 2007.

16. B. Grohmann, E. R. Spangenberg, and D. E. Sprott, "The influence of tactile input on the evaluation of retail product offerings," Journal of Retailing, vol. 83, pp. 237-245, 2007.

17. A. V. Citrin, D. E. S. Jr, E. R. Spangenberg, and M. J. Clark, "Consumer need for tactile input : An internet retailing challenge," Journal of Business Research, vol. 56, pp. 915-922, 2003.

18. J. Peck and T. L. Childers, "Individual Differences in Haptic Information Processing: The "Need for Touch" Scale," Journal of Consumer Research, vol. 30, pp. 430-442, 2003.

19. F. Kawaf and S. Tagg, "Online shopping environments in fashion shopping: An S-O-R based review," Marketing Review, vol. 12, pp. 161-180, 2012.

20. Y. J. Wang, M. S. Minor, and J. Wei, "Aesthetics and the online shopping environment: Understanding consumer responses," Journal of Retailing, vol. 87, pp. 46-58, 2011.

21. S. Shobeiri, M. Laroche, and E. Mazaheri, "Shaping e-retailer's website personality: The importance of experiential marketing," Journal of Retailing \& Consumer Services, vol. 20, pp. 102-110, 2013.

22. S. Rose, M. Clark, P. Samouel, and N. Hair, "Online Customer Experience in e-Retailing: An empirical model of Antecedents and Outcomes," Journal of Retailing, vol. 88, pp. 308-322, 2012.
23. J. S. C. Lin and H. Y. Liang, "The influence of service environments on customer emotion and service outcomes," Journal of Service Theory \& Practice, vol. 21, pp. 350-372, 2015.

24. A. M. Fiore and H. J. Jin, "Influence of image interactivity on approach responses towards an online retailer," Internet Research, vol. 13, pp. 38-48, 2003.

25. M. Fusaro, C. Y. Charron, and Y. Theoret, Generating Trust in Online Business: From Theory to Practice: Isabelle Quentin Editeur, 2003.

26. D. M. Szymanski and R. T. Hise, "E-satisfaction: an initial examination," Journal of Retailing, vol. 76, pp. 309-322, 2000.

27. H. Li, T. Daugherty, and F. Biocca, "The Role of Virtual Experience in Consumer Learning," Journal of Consumer Psychology, vol. 13, pp. 395-407, 2003.

28. G. L. Marzocchi, G. Pizzi, and D. Scarpi, "When a picture's worth a thousand words: The effects of visual construal priming on information acquisition and choice," Marketing Letters, vol. 27, pp. 1-12, 2016.

29. D. B. Mccabe and S. M. Nowlis, "The Effect of Examining Actual Products or Product Descriptions on Consumer Preference," Journal of Consumer Psychology, vol. 13, pp. 431-439, 2003.

30. Y. X. Skadberg and J. R. Kimmel, "Visitors' flow experience while browsing a Web site: its measurement, contributing factors and consequences," Computers in Human Behavior, vol. 20, pp. 403-422, 2004.

31. H. Zhao, Z. Cai, H. E. Shan, B. University, and L. T. University, "The Relationship between Online Merchandise Displaying,Online Interaction and Impulsive Buying Based on Virtual Tactility," Chinese Journal of Management, 2014.

32. J. Peck and J. W. Johnson, "Autotelic need for touch, haptics, and persuasion: The role of involvement $\uparrow, "$ Psychology \& Marketing, vol. 28, pp. 222-239, 2011.

33. R. Dhar and S. M. Nowlis, "The effect of time pressure on consumer choice deferral," Journal of Consumer Research, vol. 25, pp. 369-384, 1999.

34. K. Sepp, "Shoppers' motivations at the airport; The impact of impulse buying tendency and timepressure," 2014.

35. T. Rudolph, J. C. Bauer, and W. J. Steiner, "Pricepromotion-framing - a state-of-the-art review," Zeitschrift Für Betriebswirtschaft, vol. 80, pp. 285327, 2010 .

36. J. Y. Moon and K. H. Lee, "Influence of time pressure on the purchase decision making process in apparel shopping," Research Journal of the Costume Culture, 2013. 